\title{
Measuring oral health literacy: a scoping review of existing tools
}

Virginia Dickson-Swift ${ }^{1 *+}$, Amanda Kenny ${ }^{1 \dagger}$, Jane Farmer ${ }^{1 \dagger}$, Mark Gussy ${ }^{1+}$ and Sarah Larkins ${ }^{2+}$

\begin{abstract}
Background: This article presents findings from a scoping review of tools used to measure oral health literacy. Internationally, interest in oral health literacy is driven by oral health disparities, particularly for disadvantaged groups, with conditions such as dental caries and periodontal disease contributing substantially to the global burden of disease. The increasing focus on measuring oral health literacy aligns with reasons for measuring broader health literacy, that is, by assessing oral health literacy, decisions can be made about instigating interventions at policy and practice level to improve individual and population level oral health. There are numerous tools available that measure oral health literacy using a range of indicators.
\end{abstract}

Methods: A scoping review was designed to map the existing tools designed to measure oral health literacy $(\mathrm{OHL})$. Key search terms were developed and mapped. Selected databases were used that identified 32 relevant studies reporting a range of $\mathrm{OHL}$ tools.

Results: We identified 32 articles that reported a range of oral health literacy tools. Many of the studies used the Rapid Estimate of Adult Literacy in Dentistry (REALD) and/or the Test of Functional Health Literacy in Dentistry (ToFHLiD) that were developed from earlier tools designed to measure broader health literacy. These tools have been widely criticised for providing only an approximate measure of OHL based mainly on word recognition. A number of newer tools have included new measures of oral health literacy including numeracy and oral health conceptual knowledge however tools that measure important indicators of oral health literacy such as service navigation are rare.

Conclusions: Findings from this scoping exercise confirm our findings from preliminary scans that the majority of tools are heavily biased towards word recognition, numeracy and reading skills, rather than what this means in terms of health behaviours and service utilisation. More recent developments have attempted to incorporate other aspects considered important, including decision making and service navigation. The incorporation of these aspects into newer tools will provide oral health researchers and policy makers with further evidence of the importance of oral health literacy when designing interventions to improve oral health.

Keywords: Oral health literacy tools, Oral health, Dental health literacy, Health literacy, Scoping review

\section{Background}

This article presents findings from a scoping review of tools used to measure oral health literacy. Interest in this topic, as a domain of health literacy, and a determinant of health, has been growing since the late 1990s. In 2010, the United States Department of Health and Human Services released their 10-year national objectives

\footnotetext{
* Correspondence: V.Dickson-Swift@latrobe.edu.au

'Equal contributors

'La Trobe Rural Health School, La Trobe University, P.O. Box 199, Bendigo, Vic 3552, Australia

Full list of author information is available at the end of the article
}

for improving the health of all Americans [1]. In this document, the scale of oral health disparities, and the significant burden of oral disease were outlined. Oral health literacy was identified as key to promoting oral health and preventing oral health disease. Drawing on broader understandings of health literacy, oral health literacy was defined as the 'degree to which individuals have the capacity to obtain, process and understand basic oral health information and services needed to make appropriate health decisions'.

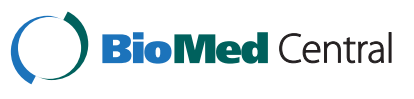


Internationally, interest in oral health literacy is driven by oral health disparities, particularly for disadvantaged groups, with conditions such as dental caries and periodontal disease contributing substantially to the global burden of disease [2-5]. In Australia $\$ 7.5 \mathrm{bn}$ was spent on dental services in $2009-10$, with $61 \%$ of this being direct out-of-pocket costs followed by $14 \%$ from health insurance funds. Australian Government contributions accounted for the remaining $25 \%$ [6]. The economic costs associated with poor oral health are well-documented $[7,8]$ and the association between oral health, and general health and wellbeing have been noted in numerous studies, with poor oral health impacting on quality of life across the lifespan $[2,7,9]$. Oral health extends beyond dental disease, with a healthy mouth central to the capacity to eat, talk and lead meaningful lives free of disease, pain or embarrassment $[3,10]$.

The importance of oral health beyond dental care is reflected in the WHO Global Oral Health Program, which is predicated on disease prevention and health promotion. Priority action areas of the WHO are directed at improving oral health literacy to drive increased knowledge and health-promoting behaviours [2] Authors argue that people who have poor levels of oral health literacy have poor dental health knowledge, increased dental visits and severity of oral health disease [11-13]. In the United States, the National Institute of Dental and Craniofacial Research (NIDCR) lobbied strongly for a focus on oral health literacy, arguing that poor oral health literacy is widespread and a causal factor in disparities in the oral health status between groups with high levels of oral health literacy and those without [3].

\section{Health literacy}

Broadly, health literacy refers to skills that establish a person's motivation and ability to access, process and use information to promote and maintain good health[14].). Increasing interest in health literacy is driven by evidence showing association between health literacy and outcomes. Low health literacy is associated with poor health knowledge, unhealthy behaviours, low usage of preventive services, poor health status, and high hospitalisation rates [15-18]. A growing body of evidence indicates that people without the health literacy skills to make sound health decisions in their everyday lives are more vulnerable and have poorer health outcomes [16,19-21].

Early health literacy measurements focused almost exclusively on reading capacity and on links between the reading skills of adults and health outcomes. Contemporary measurements extend well beyond simply the capacity to read. Nutbeam $[14,22]$ conceptualises health literacy as having three distinct levels: basic/functional (reading and writing skills for everyday life); communicative/interactional (cognitive and literacy skills combined with social skills) and critical (empowerment to handle information and have control over situations). Over the last decade, researchers have extended understandings of health literacy. Nutbeam [14,22] ,Sorensen et al. [23] with Osborne and colleagues [24] all consider writing, numeracy, speaking, listening, and understanding the healthcare system as key focal areas in any health literacy tools. The inclusion of numeracy as a key component of health literacy has been driven by claims that high percentages of the population lack the quantitative skills to understand dates and timing of medication dosages, information on appointment slips and financial information associated with healthcare [25]. In a number of studies, the ability of people, even those with good levels of reading ability, to understand numerical concepts such as probability and levels of risk has been shown to be poor [26]. It is argued that these concepts are central for promoting individual responsibility for healthcare and self-management [19,27].

Acknowledging the limitations of previous measures of health literacy, Jordan and colleagues [28] recently developed the Health Literacy Management System (HeLMS) and Osborne and colleagues [24] the Health Literacy Questionnaire (HLQ), designed to detect a wide range of components of health literacy in community settings. Researchers have identified a myriad of reasons for measuring health literacy, varying from individual screening in clinical settings to assessing larger population level understanding and comprehension [29]. However, the central tenet is that by identifying low levels of health literacy, tailored interventions can be implemented to improve health outcomes $[19,30]$.

\section{Measuring oral health literacy}

Like broader definitions of health literacy, oral health literacy refers to the capacity of a person to source, process and understand the basic information needed to make decisions about oral health. The increasing focus on measuring oral health literacy aligns with reasons for measuring broader health literacy, that is, by assessing oral health literacy, decisions can be made about instigating interventions at policy and practice level to improve individual and population level oral health [3].

The landmark 2004 United States (US) publication, Health Literacy: A Prescription to End Confusion [31] provides a summary of the development of oral health literacy tools, primarily from the US. The most widely used oral health literacy measurement tools are based on either the Rapid Estimate of Adult Literacy in Medicine (REALM) [32] or the Test of Functional Health Literacy in Adults (ToFHLA) [33]. The REALM is a word recognition test that evaluates participants' ability to read from a list of medical terms and yields grade-range estimates of reading ability. ToFHLA is used to assess peoples' literacy and numeracy skills. Findings from studies using REALM or 
ToFHLA indicate that adults with limited reading skills tend to know less about their disease or their treatment regimen, are less likely to engage in preventive services, and may be more limited in their ability to manage their disease $[15,32,33]$.

Contemporary ways of approaching oral health literacy measurement align with broader health literacy measurement trends. Parker and Jamieson [34] include understanding the causes of poor oral health, positive oral health self-care behaviours, communication with oral health providers and ability to navigate the oral healthcare system. It is argued that people with high levels of oral health literacy know where to go for oral healthcare and how to make appointments, complete forms, comply with appointment attendance, follow-up and medication [35].

Initial tools were adapted from those used to measure general health literacy. REALM was adapted as the Rapid Estimate of Adult Literacy in Dentistry (REALD). Similarly, the Test of Functional Health Literacy in Dentistry (ToFHLiD) was developed from ToFHLA. Early tools attracted the same criticisms directed at the general health literacy versions, in that they were largely word recognition tools that did not actually measure oral health literacy per se, rather they provided an approximate measure of reading skills relative to oral health content $[3,36]$.

\section{The rationale for our study}

As researchers interested in oral health, we were aware of the evidence of the link between oral health outcomes and oral health literacy. As part of our work, we started to source tools that could be used to measure oral health literacy in the populations that we work with. What was evident, through our initial scan of the literature, was that many of the tools were limited to measuring oral health literacy through testing word recognition, and reading skills. Drawing on the views of leaders in health literacy, we were keen to source tools that might take a broader approach to oral health literacy. Whilst it was evident that a number of tools have been developed, we failed to locate any comprehensive review of those currently available. This prompted our scoping review, and was the rationale for this study. Our aim in this article is to address this gap in knowledge by providing an overview of the current tools that have been developed internationally to measure oral health literacy.

\section{Methods}

A scoping review was undertaken to identify what tools or instruments currently exist that measure oral health literacy across a range of different population groups. Scoping reviews are useful to map, collate and summarise existing literature on a topic and can assist researchers to identify the nature and extent of the current research evidence. Unlike systematic reviews, the focus of a scoping review is not on the assessment of the quality of the research [37] rather, the approach supports identification of a broader range of literature, including all types of study designs [38]. The work of Arksey and O'Malley [38] provides a useful methodological framework for scoping reviews. For this study, we adopted their five-stage approach: identifying the research question; identifying relevant studies; study selection; charting the data; and collating, summarising and reporting results.

\section{Identifying the research question}

As our aim was to scope current tools designed to measure oral health literacy, we were seeking to 'generate breadth of coverage' [38] so a broad question and key terms were central. The question "What tools are currently available to measure oral health literacy?" guided the search strategy.

\section{Identifying relevant studies}

Researchers have identified the need to establish clear criteria to place boundaries around a study and balance time and cost limitations with the need for a thorough review $[39,40]$. In this study, key search terms were identified and a Boolean search string developed. Using truncated words and wild cards (in this case *) we aimed for a broad search that would capture all terms with the same root word. Our final string was oral" OR dental* AND (health AND literacy) AND tool or instrument.

An initial search of Google Scholar was carried out to determine the likely size and relevance of the key terms, but the results were not included in our findings due to the lack of replicability from this search engine [41]. To determine an appropriate time frame for the review, the Google Scholar search located minimal research on oral health literacy tools prior to 2007 so this date was chosen as appropriate for this study. Databases searched included CINAHL, ProQuest, Informit, Pub Med and Medline. International studies designed for specific cultural groups were included to provide a comprehensive overview of the tools utilised for diverse samples. A search of the Cochrane Library located one registered trial, describing an oral health literacy intervention protocol for Indigenous adults in an Australian rural setting [42]. Inclusion and exclusion criteria, consistent with our review purpose, were developed and are outlined in Table 1.

\section{Study selection}

Using the developed search terms, 239 articles were identified that used various oral health literacy tools. After deletion of duplicates, 123 articles remained. The bibliographic software program Endnote X6 was used to 
Table 1 Inclusion and exclusion criteria

\begin{tabular}{|c|c|c|}
\hline Criterion & Inclusion & Exclusion \\
\hline Time period & January 2007 to September 2014 & Any study outside these dates \\
\hline Language & English & Non-English \\
\hline Type of article & $\begin{array}{l}\text { Original research article published in } \\
\text { a peer reviewed journal that provides } \\
\text { a description of a tool. The article may } \\
\text { then proceed to use the tool or report } \\
\text { of instrument or tool }\end{array}$ & $\begin{array}{l}\text { Any publication that was not } \\
\text { original research, peer-reviewed } \\
\text { journal article and/or unpublished. } \\
\text { For example, PhD theses and reports } \\
\text { were excluded. Articles that do not } \\
\text { report using a tool or instrument } \\
\text { were also excluded. }\end{array}$ \\
\hline Study focus & $\begin{array}{l}\text { Oral or dental health literacy measurement } \\
\text { tools or instruments }\end{array}$ & $\begin{array}{l}\text { No reference to oral health literacy } \\
\text { tools or instruments }\end{array}$ \\
\hline Geographical area of interest & $\begin{array}{l}\text { International studies including those with } \\
\text { specific cultural groups }\end{array}$ & Nil \\
\hline Setting & Any & $\mathrm{Nil}$ \\
\hline
\end{tabular}

import and manage references. The title, abstract and keywords of the articles were scrutinised against the inclusion and exclusion criteria with research team members agreeing and confirming the elimination of irrelevant studies. Through this process, 32 articles were included in the final review.

\section{Data charting and collation}

Taking the included studies, and consistent with the fourth and fifth stages of Arksey and O'Malley's framework, a chronological overview of the current tools used to measure oral health literacy was developed (see Table 2). Using an Excel spreadsheet, the studies were charted and summaries developed that included author, journal, publication year, research question or aim, setting, sample, and tool/instrument used (see Table 3).

\section{Findings}

The following tables summarise tools identified through the scoping review.

\section{Results and discussion}

As outlined in Tables 2 and 3, the scoping review identified several oral health literacy tools that have been used since 2007. The most frequently used are those based on the Rapid Estimate of Adult Literacy in Medicine (REALM) developed by Davis and colleagues in 1993 [32]. Adaptations to measure oral health literacy include REALD 99 [43], REALD-30 [44-46], REALM-D [46,48], and most recently, REALMD-20 [48]. The REALD tools are essentially word recognition tests that consist of dental terms from the American Dental Association Glossary of Common Dental Terminology and patient education materials [44-48]. The tools have reportedly shown to be valid and reliable in measuring word recognition. Adding 69 new words to REALD-30, thereby creating REALD-99, did not improve results sufficiently to justify extending the list of dental words [43]. Gironda and colleagues [49] developed a shortened version, REALMD-20, for clinicians to detect limited medical/ dental health literacy in patients attending for treatment in dental/medical clinics. The authors acknowledge that the tool is useful for measuring the reading ability of patients and whilst not an effective measure of comprehensive health literacy, it does provide clinicians with a useful tool to use as a screening instrument.

The other popular oral health literacy tool identified in the review is based on the Test of Functional Health Literacy in Adults (ToFHLA) [33], a widely used measure of health literacy. This instrument, the Test of Functional Health Literacy in Dentistry (ToFHLiD), was developed by Gong and colleagues [50] and consists of a 68 -item reading comprehension section and a 12 -item numeracy section. Initial validation of ToFHLiD showed a low internal reliability but a strong convergent validity since the ToFHLiD scores were highly correlated to the REALD-99 scores. In addition, ToFHLiD showed a moderate ability to discriminate between dental and medical literacy. Despite these limitations it is often used in conjunction with other tools designed to measure oral health literacy levels (see Table 3).

In more recent years a variety of other oral health literacy measurements tools have been developed. The Oral Health Literacy Instrument (OHLI) was developed by Sabbahi et al. [11] for use with adult dental patients. This tool (like the ToFHLA) contains both reading comprehension and numeracy sections. The reading comprehension is a 38 item test with words omitted from one passage on dental caries and another on periodontal disease. The numeracy section has 19 items to test comprehension of directions for taking common prescriptions associated with dental treatment, post extraction instructions and dental appointments. Sabahhi and colleagues added an oral health knowledge test to the tool that was 
Table 2 Chronological overview of oral health literacy tools

\begin{tabular}{|c|c|c|c|c|}
\hline Abbreviation & Name of tool & Year & Authors & Type of tool \\
\hline REALD-99 & Rapid Estimate of Adult Literacy in Dentistry & 2007 & Richman et al. & 99 item word recognition \\
\hline REALD-30 & Rapid Estimate of Adult Literacy in Dentistry -30 & 2007 & Lee et al. & $\begin{array}{l}30 \text { item word recognition common } \\
\text { dental words }\end{array}$ \\
\hline ToFHLiD & Test of Functional Health Literacy in Dentistry & 2007 & Gong et al. & $\begin{array}{l}\text { Reading comprehension and numeracy } \\
68 \text { item reading comprehension and } \\
12 \text { item numeracy }\end{array}$ \\
\hline $\mathrm{OHLI}$ & Oral Health Literacy Instrument & 2009 & Sabbahi et al. & Reading comprehension and numeracy \\
\hline REALM-D & $\begin{array}{l}\text { Rapid Estimate of Adult Literacy in Medicine } \\
\text { and Dentistry }\end{array}$ & 2010 & Atchinson et al. & 84 item word recognition \\
\hline $\mathrm{CMOHK}$ & Comprehensive Measure of Oral Health Knowledge & 2010 & Macek et al. & 44 questions conceptual knowledge \\
\hline BHLOHKP & $\begin{array}{l}\text { Baltimore Health Literacy and Oral Health Knowledge } \\
\text { Project survey }\end{array}$ & 2011 & Macek et al. & $\begin{array}{l}44 \text { item questionnaire conceptual } \\
\text { knowledge across } 4 \text { domains }\end{array}$ \\
\hline \multirow[t]{2}{*}{ HKREALD-30 } & \multirow[t]{2}{*}{ Hong Kong Rapid Estimate of Adult Literacy in Dentistry } & 2012 & Wong et al. & \multirow{2}{*}{$\begin{array}{l}\text { Adaptation of the REALD-99 translated } \\
\text { to Chinese and shortened to the REALD-30 }\end{array}$} \\
\hline & & 2013 & Bridges et al. & \\
\hline OHLA-S & Oral Health Literacy Assessment-Spanish & 2012 & Lee et al. & $\begin{array}{l}\text { Developed using the REALD- } 30 \text { word } \\
\text { recognition and comprehension }\end{array}$ \\
\hline OHLA-E & Oral Health Literacy Assessment-English & 2012 & Lee et al. & $\begin{array}{l}\text { Developed using the REALD-30 word } \\
\text { recognition and comprehension }\end{array}$ \\
\hline REALMD-20 & Rapid Estimate of Adult Literacy in Dentistry-20 & 2013 & Gironda et al. & 20 item word recognition \\
\hline \multirow[t]{2}{*}{ HKOHLAT-P } & \multirow{2}{*}{$\begin{array}{l}\text { Hong Kong Oral Health Literacy Assessment Task } \\
\text { for Paediatric Dentistry }\end{array}$} & 2013 & Wong et al. & \multirow[t]{2}{*}{ Mainly literacy and numeracy tasks } \\
\hline & & 2013 & Bridges et al. & \\
\hline OHL-AQ & Oral Health Literacy Adults Questionnaire & 2013 & Sistani et al. & $\begin{array}{l}17 \text { items in } 4 \text { sections, reading comprehension, } \\
\text { numeracy, literacy and decision making }\end{array}$ \\
\hline HeLD & Health Literacy in Dentistry & 2013 & Jones et al. & Modelled on the HeLMS \\
\hline
\end{tabular}

designed to evaluate the patients' general dental knowledge to be used as a predictor of functional health literacy. The knowledge test consists of seven pictures depicting 17 labelled items such as perioral and intraoral structures, oral diseases and conditions, dental fillings, a dental prosthesis, and different oral hygiene aids. To complete this test patients were asked to match the pictures to the words. Used with a sample of 100 patients it was shown to be a valid and reliable instrument when compared to other OHL tools. The authors acknowledge that the OHLI measures the patient's ability to perform oral health literacy-related tasks that require reading, comprehension and numeracy skills and whilst it provides a useful estimate of these abilities it does not capture the full complement of literacy skills. The authors conclude that more work is needed to investigate the instrument's predictive validity and sensitivity to change using oral health outcomes with population groups known to be at high risk of low functional oral health literacy [11].

In 2010, Macek [51] and colleagues used a combination of the REALM, the Short Test of Functional Health Literacy in Adults (Short-TOFHLA) and later a new survey they developed to explore conceptual oral health knowledge [52]. These were administered to 100 adults in Baltimore. The respondents were also asked about socio-demographics, dental health, and utilization of dental services. Psychometric analysis was used to identify a subset of oral health knowledge questions from the new survey instrument. The resulting Comprehensive Measure of Oral Health Knowledge (CMOHK) was categorized into three levels of knowledge (poor, fair, good). This preliminary study yielded a new measure of oral health conceptual knowledge, available for use in future oral health literacy studies.

Similarly many researchers interested in exploring oral health literacy with low income populations have utlised the REALD-30 and oral hygiene behaviours to investigate the association of female caregivers' oral health literacy with their knowledge, behaviours and the reported oral health status of their young children [13,45,51-56]. The sample for these studies were drawn exclusively from those enrolled in the Women's Infants and Children's (WIC) supplemental nutrition program in North Carolina.

Few tools had been adapted for specific populations or cultural groupings. The Hong Kong Rapid Estimate of Adult Literacy in Dentistry (HKREALD-30) [57,58], the Hong Kong Oral Health Literacy Assessment Task for Paediatric Dentistry (HKOHLAT-P) [56,58-60], and the Oral Health Literacy Assessment-Spanish (OHLA-S) 
Table 3 Overview of studies using oral health literacy tools 2007-2013

\begin{tabular}{|c|c|c|c|c|c|c|c|c|}
\hline Authors & Year & Title & Journal & Aim & Sample & $\mathrm{n}=$ & Setting & Tool used \\
\hline $\begin{array}{l}\text { Gong, D., Lee, J., } \\
\text { Rozier, G., Pahel, B., } \\
\text { Richman, J., Vann, W. }\end{array}$ & 2007 & $\begin{array}{l}\text { Development and } \\
\text { testing of the Test } \\
\text { of Functional Health } \\
\text { Literacy in Dentistry } \\
\text { (ToFHLiD) }\end{array}$ & $\begin{array}{l}\text { Journal of Public } \\
\text { Health Dentistry }\end{array}$ & $\begin{array}{l}\text { To evaluate the reliability } \\
\text { and validity of the ToFHLiD }\end{array}$ & $\begin{array}{l}\text { Parents of } \\
\text { paediatric } \\
\text { patients }\end{array}$ & 102 & $\begin{array}{l}\text { Caregivers of paediatric } \\
\text { dental patients seeking } \\
\text { care in two dental clinics } \\
\text { in North Carolina }\end{array}$ & ToFHLiD \\
\hline $\begin{array}{l}\text { Jones, M., Lee, J., } \\
\text { Rozier, G. }\end{array}$ & 2007 & $\begin{array}{l}\text { Oral health literacy } \\
\text { among adult patients } \\
\text { seeking dental care }\end{array}$ & $\begin{array}{l}\text { Journal of the } \\
\text { American Dental } \\
\text { Association }\end{array}$ & $\begin{array}{l}\text { To examine the association } \\
\text { of knowledge, dental care } \\
\text { visits and oral health status } \\
\text { with oral health literacy in } \\
\text { dental patients }\end{array}$ & $\begin{array}{l}\text { Adult } \\
\text { patients }\end{array}$ & 101 & $\begin{array}{l}\text { Convenience sample of } \\
\text { adult patients presenting } \\
\text { for treatment at private } \\
\text { dental practices in North } \\
\text { Carolina }\end{array}$ & $\begin{array}{l}\text { REALD-30 and } \\
\text { short interview }\end{array}$ \\
\hline $\begin{array}{l}\text { Lee, J., Rozier, G., } \\
\text { Lee, S., Bender, D., } \\
\text { Ruiz, R. }\end{array}$ & 2007 & $\begin{array}{l}\text { Development of a word } \\
\text { recognition instrument } \\
\text { to test health literacy in } \\
\text { dentistry: The REALD-30- } \\
\text { A brief communication }\end{array}$ & $\begin{array}{l}\text { Journal of Public } \\
\text { Health Dentistry }\end{array}$ & $\begin{array}{l}\text { To develop and pilot test a } \\
\text { dental word recognition } \\
\text { instrument }\end{array}$ & $\begin{array}{l}\text { Adult } \\
\text { patients }\end{array}$ & 200 & $\begin{array}{l}\text { Ambulatory Care Centre } \\
\text { at the University of North } \\
\text { Carolina Hospital }\end{array}$ & $\begin{array}{l}\text { REALD-30 and } \\
\text { interview that } \\
\text { included the } \\
\text { TOFHLA \& } \\
\text { REALM \& } \\
\text { OHIP-14 }\end{array}$ \\
\hline $\begin{array}{l}\text { Richman, K., Lee, J., } \\
\text { Rozier, G., Gong, D., } \\
\text { Pahel, B., Vann, W. }\end{array}$ & 2007 & $\begin{array}{l}\text { Evaluation of a word } \\
\text { recognition instrument } \\
\text { to test health literacy in } \\
\text { dentistry: The REALD-99 }\end{array}$ & $\begin{array}{l}\text { American } \\
\text { Association of Public } \\
\text { Health Dentistry }\end{array}$ & $\begin{array}{l}\text { To evaluate a dental health } \\
\text { literacy word recognition } \\
\text { instrument }\end{array}$ & $\begin{array}{l}\text { Parents of } \\
\text { paediatric } \\
\text { patients }\end{array}$ & 102 & $\begin{array}{l}\text { Parents and caregivers of } \\
\text { paediatric dental patients } \\
\text { from the UNC-CH School } \\
\text { of Dentistry Paediatric } \\
\text { Dental Clinics and from } \\
\text { Orange County Dental Clinics }\end{array}$ & REALD-99 \\
\hline Jackson, R., Eckert, G. & 2008 & $\begin{array}{l}\text { Health literacy in an adult } \\
\text { dental research population: } \\
\text { A pilot study }\end{array}$ & $\begin{array}{l}\text { American } \\
\text { Association of } \\
\text { Public Health } \\
\text { Dentistry }\end{array}$ & $\begin{array}{l}\text { To gather data concerning } \\
\text { the level of health literacy } \\
\text { in adults who frequently } \\
\text { volunteer for clinical research } \\
\text { programs }\end{array}$ & $\begin{array}{l}\text { Adults } \\
\text { enrolled in } \\
\text { the Oral } \\
\text { Health } \\
\text { Research } \\
\text { Institute } \\
\text { School of } \\
\text { Dentistry }\end{array}$ & 100 & $\begin{array}{l}\text { Oral Health Research Institute } \\
\text { of Indiana University School } \\
\text { of Dentistry }\end{array}$ & S-ToFHLA \\
\hline $\begin{array}{l}\text { Sabbahi.D., } \\
\text { Lawrence, H., } \\
\text { Limeback, H., } \\
\text { Rootman, I. }\end{array}$ & 2009 & $\begin{array}{l}\text { Development and } \\
\text { evaluation of an oral } \\
\text { health literacy instrument } \\
\text { for adults }\end{array}$ & $\begin{array}{l}\text { Community } \\
\text { Dentistry and } \\
\text { Oral Epidemiology }\end{array}$ & $\begin{array}{l}\text { To develop and validate an } \\
\text { instrument to measure } \\
\text { functional oral health literacy } \\
\text { of adults }\end{array}$ & $\begin{array}{l}\text { Adult } \\
\text { patients }\end{array}$ & 100 & $\begin{array}{l}\text { Convenience sample of } \\
\text { patients attending the } \\
\text { Faculty of Dentistry clinics } \\
\text { at the University of Toronto }\end{array}$ & $\begin{array}{l}\text { Oral Health } \\
\text { Knowledge } \\
\text { test, OHLI, } \\
\text { ToHFLA }\end{array}$ \\
\hline $\begin{array}{l}\text { Atchison, K., } \\
\text { Gironda, M., } \\
\text { Messadi, D., } \\
\text { Der-Martirosian, C. }\end{array}$ & 2010 & $\begin{array}{l}\text { Screening for oral health } \\
\text { literacy in an urban } \\
\text { dental clinic }\end{array}$ & $\begin{array}{l}\text { Journal of Public } \\
\text { Health Dentistry }\end{array}$ & $\begin{array}{l}\text { To evaluate a health literacy } \\
\text { instrument based on the } \\
\text { REALM that incorporates } \\
\text { dental and medical terms } \\
\text { into one } 84 \text {-item REALM-D } \\
\text { measure and determine } \\
\text { its association with patient } \\
\text { characteristics of a culturally } \\
\text { diverse dental clinic population }\end{array}$ & $\begin{array}{l}\text { Adult } \\
\text { patients }\end{array}$ & 200 & $\begin{array}{l}\text { Oral health clinic urban } \\
\text { centre Los Angeles, California }\end{array}$ & REALM-D \\
\hline
\end{tabular}

est health literacy in

paediatric

Drange County Dental Clinics

in adults who frequently

volunteer for clinical research

Research

School of

Lawrence, $\mathrm{H}$,

Rootman,

Messadi, D

Der-Martirosian,

\section{health literacy instrument}

Screening for oral health

literacy in an urban

ntal clinic 
Table 3 Overview of studies using oral health literacy tools 2007-2013 (Continued)

\begin{tabular}{|c|c|c|c|c|c|c|c|c|}
\hline $\begin{array}{l}\text { Macek, M., Haynes, } \\
\text { D., Wells, W., } \\
\text { Bauer-Leffler, S., } \\
\text { Cotten, P., Parker, R. }\end{array}$ & 2010 & $\begin{array}{l}\text { Measuring conceptual } \\
\text { health knowledge in the } \\
\text { context of oral health } \\
\text { literacy: preliminary results }\end{array}$ & $\begin{array}{l}\text { Journal of Public } \\
\text { Health Dentistry }\end{array}$ & $\begin{array}{l}\text { To assess the validity and } \\
\text { reliability of a new instrument } \\
\text { and describe conceptual oral } \\
\text { health knowledge among a } \\
\text { sample of low-income adults }\end{array}$ & $\begin{array}{l}\text { Adult } \\
\text { residents of } \\
\text { Baltimore }\end{array}$ & 100 & $\begin{array}{l}\text { Baltimore residents randomly } \\
\text { selected from a list of those } \\
\text { that had landlines }\end{array}$ & $\begin{array}{l}\text { REALM and } \\
\text { the S-ToFHLA } \\
\text { to develop } \\
\text { CMOHK }\end{array}$ \\
\hline Parker, E., Jamieson, L. & 2010 & $\begin{array}{l}\text { Associations between } \\
\text { Indigenous Australian } \\
\text { oral health literacy } \\
\text { and self-reported oral } \\
\text { health outcomes }\end{array}$ & BMC Oral Health & $\begin{array}{l}\text { To determine oral health } \\
\text { literacy (REALD-30) and oral } \\
\text { health literacy-related outcome } \\
\text { associations, and to calculate } \\
\text { if oral health literacy-related } \\
\text { outcomes are risk indicators } \\
\text { for poor self-reported oral } \\
\text { health among rural-dwelling } \\
\text { Indigenous Australians }\end{array}$ & $\begin{array}{l}\text { Indigenous } \\
\text { adults }\end{array}$ & 468 & $\begin{array}{l}\text { Convenience sample of } \\
\text { Indigenous adults living in } \\
\text { the Port Augusta region } \\
\text { of Australia }\end{array}$ & $\begin{array}{l}\text { REALD-30 } \\
\text { and measures } \\
\text { from OHL-14 }\end{array}$ \\
\hline $\begin{array}{l}\text { Vann, W., Lee, J., Baker, } \\
\text { D., Divaris, K. }\end{array}$ & 2010 & $\begin{array}{l}\text { Oral health literacy among } \\
\text { female caregivers: Impact } \\
\text { on oral health outcomes } \\
\text { in early childhood }\end{array}$ & $\begin{array}{l}\text { Journal of Dental } \\
\text { Research }\end{array}$ & $\begin{array}{l}\text { To investigate the association } \\
\text { of female caregivers' oral } \\
\text { health literacy with their } \\
\text { knowledge, behaviours and } \\
\text { the reported oral health } \\
\text { status of their young children }\end{array}$ & $\begin{array}{l}\text { Child/ } \\
\text { caregiver } \\
\text { dyads from } \\
\text { the } \\
\text { Carolina } \\
\text { Oral Health } \\
\text { Literacy } \\
\text { Project }\end{array}$ & 1273 & $\begin{array}{l}\text { Caregivers and children } \\
\text { enrolled in the Women's } \\
\text { Infants and Children's (WIC) } \\
\text { Supplemental Nutrition } \\
\text { Program in North Carolina }\end{array}$ & $\begin{array}{l}\text { REALD- } 30 \text { and } \\
\text { oral hygiene } \\
\text { behaviours }\end{array}$ \\
\hline $\begin{array}{l}\text { Wells, P., Caplan, D., } \\
\text { Strauss, R., Bell, D., } \\
\text { George, M. }\end{array}$ & 2010 & $\begin{array}{l}\text { An oral health survey of } \\
\text { the Lumbee tribe in } \\
\text { South-eastern North Carolina }\end{array}$ & $\begin{array}{l}\text { The Journal of } \\
\text { Dental Hygiene }\end{array}$ & $\begin{array}{l}\text { To evaluate access to dental } \\
\text { care issues, oral health } \\
\text { knowledge and oral } \\
\text { health-related quality of } \\
\text { life of the Lumbee tribe }\end{array}$ & $\begin{array}{l}\text { Adult } \\
\text { Lumbee } \\
\text { tribe } \\
\text { members }\end{array}$ & 118 & $\begin{array}{l}\text { Convenience sample of } \\
\text { American Indian attending } \\
\text { the Lumbee Tribe } \\
\text { Homecoming in North Carolina }\end{array}$ & $\begin{array}{l}\text { OHIP-14 and } \\
\text { survey }\end{array}$ \\
\hline $\begin{array}{l}\text { Lee, Y., Divaris, K., } \\
\text { Baker, A. Vann, W. }\end{array}$ & 2011 & $\begin{array}{l}\text { The relationship of oral } \\
\text { health literacy with oral } \\
\text { health-related quality of } \\
\text { life in a multi-racial sample } \\
\text { of low-income female } \\
\text { caregivers }\end{array}$ & $\begin{array}{l}\text { Health and Quality } \\
\text { of Life Outcomes }\end{array}$ & $\begin{array}{l}\text { To investigate the association } \\
\text { between oral health literacy } \\
(\mathrm{OHL}) \text { and Oral-Health } \\
\text { Related Quality of Life } \\
\text { (OHRQoL) and explore the } \\
\text { racial differences therein } \\
\text { among a low-income } \\
\text { community-based group } \\
\text { of female WIC participants. }\end{array}$ & $\begin{array}{l}\text { Low } \\
\text { income } \\
\text { adult } \\
\text { females } \\
\text { enrolled in } \\
\text { WIC } \\
\text { program }\end{array}$ & 1405 & $\begin{array}{l}\text { Community setting of adult } \\
\text { women enrolled in the Women, } \\
\text { Infants and Children's(WIC) } \\
\text { Supplemental Nutrition Program } \\
\text { in } 7 \text { counties in North Carolina. }\end{array}$ & OHIP-14, REALD-30 \\
\hline $\begin{array}{l}\text { Lee, J., Divaris, K., } \\
\text { Baker, A., Rozier. } \\
\text { R., Lee, S., Vann, W. }\end{array}$ & 2011 & $\begin{array}{l}\text { Oral health literacy levels } \\
\text { among a low-income WIC } \\
\text { population }\end{array}$ & $\begin{array}{l}\text { Journal of Public } \\
\text { Health Dentistry }\end{array}$ & $\begin{array}{l}\text { To determine oral health } \\
\text { literacy }(\mathrm{OHL}) \text { levels and } \\
\text { explore potential racial } \\
\text { differences in a low-income } \\
\text { population }\end{array}$ & $\begin{array}{l}\text { Care givers } \\
\text { of } \\
\text { paediatric } \\
\text { patients }\end{array}$ & 1405 & $\begin{array}{l}\text { Community setting of adult } \\
\text { women enrolled in the Women, } \\
\text { Infants and Children's(WIC) } \\
\text { Supplemental Nutrition Program } \\
\text { in } 7 \text { counties in North Carolina. }\end{array}$ & $\begin{array}{l}\text { REALD-30 and } \\
\text { survey }\end{array}$ \\
\hline $\begin{array}{l}\text { Macek, M., Manski, } \\
\text { M., Schneiderman, } \\
\text { T., Meakin, S., Haynes, } \\
\text { D., Wells, W., } \\
\text { Bauer-Leffler, S., }\end{array}$ & 2011 & $\begin{array}{l}\text { Knowledge of oral health } \\
\text { issues among low-income } \\
\text { Baltimore adult: A pilot study }\end{array}$ & $\begin{array}{l}\text { Journal of Dental } \\
\text { Hygiene }\end{array}$ & $\begin{array}{l}\text { Pilot study to document } \\
\text { conceptual knowledge of } \\
\text { oral health among low } \\
\text { income adults in Baltimore }\end{array}$ & $\begin{array}{l}\text { Low } \\
\text { income } \\
\text { adults in } \\
\text { Baltimore }\end{array}$ & 100 & $\begin{array}{l}\text { Baltimore residents randomly } \\
\text { selected from a list of those } \\
\text { that had landlines }\end{array}$ & BHLOHKP \\
\hline
\end{tabular}


Table 3 Overview of studies using oral health literacy tools 2007-2013 (Continued)

\begin{tabular}{|c|c|c|c|c|c|c|c|c|}
\hline $\begin{array}{l}\text { Stucky, B., Lee, J., } \\
\text { Lee, S., Rozier, R., }\end{array}$ & 2011 & $\begin{array}{l}\text { Development of the } \\
\text { two-stage Rapid Estimate } \\
\text { of Adult Literacy in Dentistry }\end{array}$ & $\begin{array}{l}\text { Community } \\
\text { Dentistry and Oral } \\
\text { Epidemiology }\end{array}$ & $\begin{array}{l}\text { To revise the } 30 \text { item Rapid } \\
\text { Estimate of Adult Literacy } \\
\text { in Dentistry (REALD-30) } \\
\text { into a more efficient and } \\
\text { easier-to-use two-stage model }\end{array}$ & $\begin{array}{l}\text { Low } \\
\text { income } \\
\text { adults } \\
\text { (primarily } \\
\text { women) } \\
\text { enrolled in } \\
\text { the WIC } \\
\text { program }\end{array}$ & 1405 & $\begin{array}{l}\text { Low income adults (primarily } \\
\text { women) enrolled in the } \\
\text { North Carolina WIC } \\
\text { supplemental nutrition program }\end{array}$ & $\begin{array}{l}\text { REALD-30, } \\
\text { TS-REALD }\end{array}$ \\
\hline $\begin{array}{l}\text { Lee, J., Divaris, K.. } \\
\text { Baker, A., Rozier, R., } \\
\text { Vann, W. }\end{array}$ & 2012 & $\begin{array}{l}\text { The relationship of oral } \\
\text { health literacy and self-efficacy } \\
\text { with oral health status and } \\
\text { dental neglect }\end{array}$ & $\begin{array}{l}\text { American Journal } \\
\text { of Public Health }\end{array}$ & $\begin{array}{l}\text { To examine the association } \\
\text { of oral health literacy }(\mathrm{OHL}) \\
\text { with oral health status }(\mathrm{OHS}) \\
\text { and dental neglect }(\mathrm{DN}) \text { and } \\
\text { whether self efficacy mediated } \\
\text { or modified these associations }\end{array}$ & $\begin{array}{l}\text { Female } \\
\text { caregivers }\end{array}$ & 1280 & $\begin{array}{l}\text { Community setting of adult } \\
\text { women enrolled in the } \\
\text { Women, Infants and Children's } \\
\text { WIC Supplemental Nutrition } \\
\text { Program (in } 7 \text { counties in } \\
\text { North Carolina. }\end{array}$ & REALD-30 \\
\hline $\begin{array}{l}\text { Lee, J., Stucky, B., } \\
\text { Rozier, G., Lee, S., } \\
\text { Zeldin, L. }\end{array}$ & 2012 & $\begin{array}{l}\text { Oral health literacy assessment: } \\
\text { development of an oral health } \\
\text { literacy instrument for Spanish } \\
\text { speakers }\end{array}$ & $\begin{array}{l}\text { Journal of Public } \\
\text { Health Dentistry }\end{array}$ & $\begin{array}{l}\text { To develop an oral health } \\
\text { literacy instrument for } \\
\text { Spanish-speaking adults, } \\
\text { evaluate its psychometric } \\
\text { properties and determine } \\
\text { its comparability to the } \\
\text { English version }\end{array}$ & $\begin{array}{l}\text { Adults } \\
\text { fluent in } \\
\text { English or } \\
\text { Spanish at } \\
\text { various } \\
\text { sites in } \\
\text { North } \\
\text { Carolina }\end{array}$ & 405 & $\begin{array}{l}\text { Sites that included WIC } \\
\text { clinics in various regions } \\
\text { of North Carolina, Early Head } \\
\text { Start Centre and a continuity } \\
\text { care clinic in North Carolina }\end{array}$ & OHLA, OHLA-S \\
\hline $\begin{array}{l}\text { Parker, E., Misan, G., } \\
\text { Chong, A., Mills, A., } \\
\text { Roberts-Thomson, K., } \\
\text { Horowitz, A., Jamieson, L. }\end{array}$ & 2012 & $\begin{array}{l}\text { An oral health literacy } \\
\text { intervention for Indigenous } \\
\text { adults living in a rural setting } \\
\text { in Australia }\end{array}$ & BMC Public Health & $\begin{array}{l}\text { To determine if implementation } \\
\text { of a functional, context-specific } \\
\text { oral health literacy intervention } \\
\text { improves oral health } \\
\text { literacy-related outcomes } \\
\text { measured by use of dental } \\
\text { services, and assessment of } \\
\text { oral health knowledge, oral } \\
\text { health self-care and oral } \\
\text { health-related self-efficacy }\end{array}$ & $\begin{array}{l}\text { Indigenous } \\
\text { adults }\end{array}$ & 400 & $\mathrm{RCT}$ with randomisation & $\begin{array}{l}\text { Adaptation of } \\
\text { the HeLM }\end{array}$ \\
\hline $\begin{array}{l}\text { Wehmeyer, M., } \\
\text { Corwin, C., Guthmiller, } \\
\text { J., Lee, J., }\end{array}$ & 2012 & $\begin{array}{l}\text { The impact of oral health } \\
\text { literacy on periodontal } \\
\text { health status }\end{array}$ & $\begin{array}{l}\text { American Association } \\
\text { of Public Health } \\
\text { Dentistry }\end{array}$ & $\begin{array}{l}\text { To describe the oral health } \\
\text { literacy }(\mathrm{OHL}) \text { among } \\
\text { periodontal patients and to } \\
\text { examine its association with } \\
\text { periodontal health status }\end{array}$ & $\begin{array}{l}\text { Adult } \\
\text { patients }\end{array}$ & 121 & $\begin{array}{l}\text { Convenience sample of adult } \\
\text { patients presenting for initial } \\
\text { consultation appointment to } \\
\text { the University of North Carolina } \\
\text { Graduate Periodontology Clinic }\end{array}$ & $\begin{array}{l}\text { REALD- } 30 \text { and } \\
\text { survey and } \\
\text { periodontal exam }\end{array}$ \\
\hline $\begin{array}{l}\text { Wong, H., Bridges, S., } \\
\text { You. C., McGrath, C., } \\
\text { Au, T., Parthasarathy, D. }\end{array}$ & 2012 & $\begin{array}{l}\text { Development and } \\
\text { validation of Hong } \\
\text { Kong Rapid Estimate } \\
\text { of Adult Literacy in } \\
\text { Dentistry }\end{array}$ & $\begin{array}{l}\text { Journal of } \\
\text { Investigative and } \\
\text { Clinical Dentistry }\end{array}$ & $\begin{array}{l}\text { To develop and validate an } \\
\text { instrument, the Hong Kong } \\
\text { Rapid Estimate of Adult } \\
\text { Literacy in Dentistry }\end{array}$ & $\begin{array}{l}\text { Parents of } \\
\text { paediatric } \\
\text { dental } \\
\text { patients }\end{array}$ & 200 & $\begin{array}{l}\text { Convenience sample of parents } \\
\text { of paediatric patients attending } \\
\text { the Paediatric Dentistry Clinic } \\
\text { in Hong Kong }\end{array}$ & $\begin{array}{l}\text { REALD-99 } \\
\text { translated to } \\
\text { Chinese and } \\
\text { modified to } \\
\text { the HKREALD-30 } \\
\text { and clinical } \\
\text { examination }\end{array}$ \\
\hline
\end{tabular}


Table 3 Overview of studies using oral health literacy tools 2007-2013 (Continued)

\begin{tabular}{|c|c|c|c|c|c|c|c|c|}
\hline $\begin{array}{l}\text { Bridges, S., Parthasarathy, } \\
\text { D., Au, T., Wong, H., Yiu, } \\
\text { C., McGrath, C. }\end{array}$ & 2013 & $\begin{array}{l}\text { Development of functional } \\
\text { oral health literacy assessment } \\
\text { instruments: Application } \\
\text { of literacy and cognitive } \\
\text { theories }\end{array}$ & $\begin{array}{l}\text { Journal of Public } \\
\text { Health Dentistry }\end{array}$ & $\begin{array}{l}\text { Development of a new I } \\
\text { iteracy assessment instrument } \\
\text { to establish content and face } \\
\text { validity. }\end{array}$ & $\begin{array}{l}\text { care givers } \\
\text { of } \\
\text { paediatric } \\
\text { patients }\end{array}$ & $\begin{array}{l}\text { Not } \\
\text { specified }\end{array}$ & $\begin{array}{l}\text { Various clinics and community } \\
\text { settings in Hong Kong }\end{array}$ & HKOHLAT-P \\
\hline $\begin{array}{l}\text { Bridges, S., Parthasarathy, } \\
\text { D., Wong, H., Yiu, C., Au, } \\
\text { T., McGrath, C. }\end{array}$ & 2013 & $\begin{array}{l}\text { The relationship between } \\
\text { caregiver functional oral } \\
\text { health literacy and child } \\
\text { oral health status }\end{array}$ & $\begin{array}{l}\text { Patient Education } \\
\text { and Counselling }\end{array}$ & $\begin{array}{l}\text { To describe the relationship } \\
\text { between caregiver's oral health } \\
\text { literacy }(\mathrm{OHL}) \text { and the oral } \\
\text { health status of their children in } \\
\text { an Asian population }\end{array}$ & $\begin{array}{l}\text { care givers } \\
\text { of } \\
\text { paediatric } \\
\text { patients }\end{array}$ & 301 & $\begin{array}{l}\text { Child/caregiver dyads from } \\
\text { kindergarten in Hong Kong }\end{array}$ & $\begin{array}{l}\text { HKREALD-30 } \\
\text { and HKOHLAT-P }\end{array}$ \\
\hline $\begin{array}{l}\text { Gironda, Der-Martirosian, } \\
\text { C., Messadi, D., Holtzman, } \\
\text { J. Atchinson, K. }\end{array}$ & 2013 & $\begin{array}{l}\text { A brief 20-item dental/ } \\
\text { medical health literacy } \\
\text { screen (REALMD-20) }\end{array}$ & $\begin{array}{l}\text { Journal of Public } \\
\text { Health Dentistry }\end{array}$ & $\begin{array}{l}\text { To introduce a brief } 20 \text { item } \\
\text { screener for limited dental/ } \\
\text { medical health literacy among } \\
\text { adult dental patients }\end{array}$ & $\begin{array}{l}\text { Adult } \\
\text { patients } \\
\text { seeking } \\
\text { treatment } \\
\text { for the first } \\
\text { time }\end{array}$ & 200 & $\begin{array}{l}\text { Patients seeking treatment } \\
\text { for the first time at an Oral } \\
\text { Diagnosis Clinic at a School } \\
\text { of Dentistry in the US. }\end{array}$ & REALMD-20 \\
\hline $\begin{array}{l}\text { Hom, J., Lee, J., Divaris, } \\
\text { K., Baker, A., Vann, W. }\end{array}$ & 2013 & $\begin{array}{l}\text { Oral health literacy and } \\
\text { knowledge among } \\
\text { patients who are pregnant } \\
\text { for the first time }\end{array}$ & $\begin{array}{l}\text { The Journal of the } \\
\text { American Dental } \\
\text { Association }\end{array}$ & $\begin{array}{l}\text { To determine the levels of and } \\
\text { examine the associations of } \\
\text { oral health literacy }(\mathrm{OHL}) \text { and } \\
\text { oral health knowledge in low } \\
\text { income patients who were } \\
\text { pregnant for the first time }\end{array}$ & $\begin{array}{l}\text { Low } \\
\text { income } \\
\text { women } \\
\text { pregnant } \\
\text { for the first } \\
\text { time }\end{array}$ & 119 & $\begin{array}{l}\text { Subset of women pregnant } \\
\text { for the first time in WIC } \\
\text { project in North Carolina }\end{array}$ & $\begin{array}{l}\text { REALD-30 and } \\
\text { OHL survey }\end{array}$ \\
\hline $\begin{array}{l}\text { Jamieson, L., Divaris, K., } \\
\text { Parker, E., Lee, J. }\end{array}$ & 2013 & $\begin{array}{l}\text { Oral health literacy } \\
\text { comparisons between } \\
\text { Indigenous Australians } \\
\text { and American Indians }\end{array}$ & $\begin{array}{l}\text { Community Dental } \\
\text { Health }\end{array}$ & $\begin{array}{l}\text { To compare oral health literacy } \\
\text { (OHL) levels between two } \\
\text { profoundly disadvantaged } \\
\text { groups, Indigenous Australians } \\
\text { and American Indians and to } \\
\text { explore the differences in } \\
\text { socio-demographic, dental ser- } \\
\text { vice utilisation, self-reported } \\
\text { oral health indicators, and oral } \\
\text { health-related quality of life cor- } \\
\text { relates of OHL among the } \\
\text { above. }\end{array}$ & $\begin{array}{l}\text { Indigenous } \\
\text { adults } \\
\text { (Australia), } \\
\text { American } \\
\text { Indians } \\
\text { (North } \\
\text { Carolina) }\end{array}$ & $\begin{array}{l}468 \\
\text { (Aus) } \\
254 \\
\text { (USA) }\end{array}$ & $\begin{array}{l}\text { Convenience sample of } \\
\text { Indigenous adults living in } \\
\text { the Port Augusta region of } \\
\text { Australia and a convenience } \\
\text { sample of caregivers } \\
\text { attending the WIC clinics } \\
\text { at selected sites in North } \\
\text { Carolina }\end{array}$ & $\begin{array}{l}\text { REALD-30 and } \\
\text { OHP-14 }\end{array}$ \\
\hline $\begin{array}{l}\text { Jones, K., Parker, E., Mills, } \\
\text { H., Horowitz, A., Brennan, } \\
\text { D., Jamieson, L. }\end{array}$ & 2013 & $\begin{array}{l}\text { Development and } \\
\text { psychometric validation } \\
\text { of a Health Literacy in } \\
\text { Dentistry scale (HeLD) }\end{array}$ & $\begin{array}{l}\text { Community Dental } \\
\text { Health }\end{array}$ & $\begin{array}{l}\text { To develop and validate a } \\
\text { culturally-appropriate Health } \\
\text { Literacy in Dentistry (HeLD) in- } \\
\text { strument for use amongst Indi- } \\
\text { genous Australians }\end{array}$ & $\begin{array}{l}\text { Indigenous } \\
\text { adults }\end{array}$ & 209 & $\begin{array}{l}\text { Convenience sample of } \\
\text { Indigenous adults living } \\
\text { in the Port Augusta region } \\
\text { of Australia }\end{array}$ & HeLD \\
\hline $\begin{array}{l}\text { Sistani, M., Montazeri, } \\
\text { A., Yazdani, R., } \\
\text { Murtomaa, H. }\end{array}$ & 2013 & $\begin{array}{l}\text { New oral health literacy } \\
\text { instrument for public } \\
\text { health: development } \\
\text { and pilot testing }\end{array}$ & $\begin{array}{l}\text { Journal of } \\
\text { Investigative and } \\
\text { Clinical Dentistry }\end{array}$ & $\begin{array}{l}\text { To develop a functional oral } \\
\text { health literacy }(\mathrm{OHL}) \text { instrument } \\
\text { for adults including new } \\
\text { measures of literacy skills (OHL- } \\
\text { AQ) }\end{array}$ & $\begin{array}{l}\text { Adult } \\
\text { citizens } \\
\text { living in } \\
\text { Tehran }\end{array}$ & 97 & $\begin{array}{l}\text { Randomly selected } \\
\text { households in Tehran }\end{array}$ & OHL-AQ \\
\hline
\end{tabular}


Table 3 Overview of studies using oral health literacy tools 2007-2013 (Continued)

\begin{tabular}{|c|c|c|c|c|c|c|c|c|}
\hline $\begin{array}{l}\text { Sistani, M., Yazdani, R. } \\
\text { Virtanen, J., Pakdaman,A., } \\
\text { Murtomaa, H. }\end{array}$ & 2013 & $\begin{array}{l}\text { Determinants of oral } \\
\text { health: Does oral health } \\
\text { literacy matter? }\end{array}$ & ISRN Dentistry & $\begin{array}{l}\text { To evaluate oral health literacy, } \\
\text { independent of other oral } \\
\text { health determinants, as a risk } \\
\text { indicator for self-reported oral } \\
\text { health }\end{array}$ & $\begin{array}{l}\text { Adults } \\
\text { living in } \\
\text { Tehran }\end{array}$ & 1031 & $\begin{array}{l}\text { Random area sampling in } \\
\text { Tehran }\end{array}$ & $\mathrm{OHL}-\mathrm{AQ}$ \\
\hline $\begin{array}{l}\text { Sistani, M., Yazdani, R. } \\
\text { Virtanen, J., Pakdaman,A., } \\
\text { Murtomaa, H. }\end{array}$ & 2013 & $\begin{array}{l}\text { Oral health literacy and } \\
\text { information sources among } \\
\text { adults in Tehran, Iran }\end{array}$ & $\begin{array}{l}\text { Community Dental } \\
\text { Health }\end{array}$ & $\begin{array}{l}\text { To assess oral health literacy } \\
\text { level and oral health } \\
\text { information of Iranian adults in } \\
\text { Tehran, and to determine the } \\
\text { factors related to oral health } \\
\text { literacy }\end{array}$ & Adults & 1031 & $\begin{array}{l}\text { Multi-stage random sample } \\
\text { from Tehran, Iran }\end{array}$ & OHL-AQ \\
\hline $\begin{array}{l}\text { Ueno, M. Takeuchi, S., } \\
\text { Oshiro, A., Kawaguchi, Y. }\end{array}$ & 2013 & $\begin{array}{l}\text { Relationship between } \\
\text { oral health literacy and } \\
\text { oral health behaviors and } \\
\text { clinical status in Japanese } \\
\text { adults }\end{array}$ & $\begin{array}{l}\text { Journal of Dental } \\
\text { Sciences }\end{array}$ & $\begin{array}{l}\text { To investigate how oral health } \\
\text { literacy relates to oral health } \\
\text { behaviors, as well as clinical } \\
\text { dental and periodontal } \\
\text { conditions. }\end{array}$ & $\begin{array}{l}\text { Adult } \\
\text { residents of } \\
\text { Akita in } \\
\text { Japan }\end{array}$ & 518 & $\begin{array}{l}\text { Adult residents aged older } \\
\text { than } 20 \text { living in Akita, Japan }\end{array}$ & $\begin{array}{l}\text { Self administered } \\
\text { questionnaire } \\
\text { and dental exam }\end{array}$ \\
\hline $\begin{array}{l}\text { Wong, H., Bridges, S., } \\
\text { Yiu, C., McGrath, C., Au, } \\
\text { T., Parthasarathy, D., }\end{array}$ & 2013 & $\begin{array}{l}\text { Validation of the Hong } \\
\text { Kong Literacy Assessment } \\
\text { Task for Paediatric Dentistry } \\
\text { (HKOHLAT-P) }\end{array}$ & $\begin{array}{l}\text { International } \\
\text { Journal of } \\
\text { Paediatric } \\
\text { Dentistry }\end{array}$ & $\begin{array}{l}\text { To validate an original } \\
\text { instrument. The Hong Kong } \\
\text { Oral Health Literacy Assessment } \\
\text { Task (HKOHLAT-P) for paediatric } \\
\text { dentistry }\end{array}$ & $\begin{array}{l}\text { Parent/ } \\
\text { Child dyads }\end{array}$ & $\begin{array}{l}200 \\
\text { pairs }\end{array}$ & $\begin{array}{l}\text { Convenience sample of } 200 \\
\text { pairs of parents/children } \\
\text { attending the Paediatric } \\
\text { Dentistry Clinic in Hong Kong }\end{array}$ & $\begin{array}{l}\text { HKOHLAT-P, } \\
\text { ToFHLiD, } \\
\text { ECO-HIS and } \\
\text { interviews using } \\
\text { HKREALD-30 }\end{array}$ \\
\hline $\begin{array}{l}\text { Holtzman, J., Atchison, J., } \\
\text { Gironda, M., Radbod, R., } \\
\text { Gornbein, J. }\end{array}$ & 2013 & $\begin{array}{l}\text { The association between } \\
\text { oral health literacy and } \\
\text { failed appointments in } \\
\text { adults attending a } \\
\text { university-based general } \\
\text { dental clinic }\end{array}$ & $\begin{array}{l}\text { Community Dentistry } \\
\text { and Oral } \\
\text { Epidemiology }\end{array}$ & $\begin{array}{l}\text { To determine the association } \\
\text { between personal } \\
\text { characteristics, a person's oral } \\
\text { health literacy and failing to } \\
\text { show for dental appointments }\end{array}$ & Adults & 200 & $\begin{array}{l}\text { Secondary analysis of } 200 \\
\text { adult patients at a university } \\
\text { dental clinic }\end{array}$ & $\begin{array}{l}\text { REALM-D and } \\
\text { socio-demographic } \\
\text { survey }\end{array}$ \\
\hline
\end{tabular}


[54] are exceptions. Other tools have been adapted for use with specific cultural groups [34,54-66]. A recent study by Parker and Jamieson [34] used REALD-30 and oral health literacy-related outcome associations to calculate risk indicators for poor self-reported oral health among rural-dwelling Indigenous Australians. This study aimed to determine the relationship between oral health literacy, as assessed by REALD-30 and oral health literacy-related outcomes. The researchers identified individuals' oral health knowledge, oral health self-care and utilisation of dental services, to determine if these factors (often measured in existing tests of oral health literacy) are risk indicators for seven domains of poor self-reported oral health. Parker and Jamieson acknowledge the shortcomings of REALD-30 particularly that it measures word recognition only, with no test of comprehension or functional oral health literacy. The authors initially included questions from the TOFHLiD, as an attempt to measure broader aspects of oral health literacy, including reading comprehension and numerical ability but these were removed after trialling with the Indigenous reference group, members of which identified a potential lack of acceptance within their community. The researchers note that some participants felt uncomfortable with the instrument, feeling like they were being "tested" and "judged" [34]. The findings of this study confirmed that those with poorer oral health literacy, as measured by REALD-30, had poorer oral health knowledge and engaged in more harmful oral health behaviours.

Seeking to develop a reliable, valid and culturally appropriate instrument to assess oral health literacy among vulnerable groups, Jones et al developed the Health Literacy in Dentistry scale (HeLD). Using the Health Literacy Measurement Scale (HeLMS) as a foundation, a number of theoretical constructs were included which assume "a person's ability to seek, understand and use oral health information is important in being able to access and benefit from oral health care services" [63]. The HeLD has eight domains which mirror those used in the HeLMS. The HeLD accounts for the multidimensional nature of oral health literacy and encompasses the domains of communication, access, receptivity, understanding, utilisation, support and economic barriers which have all been shown to impact on oral health status. The results of a HeLD pilot with 209 Indigenous adults highlight the potential for using the instrument across a variety of health care settings whilst "still allowing reliable international comparisons to be made" [63:6]. The researchers state that results of studies utilising this tool will be of interest to all those working on OHL measurement with both marginalised and mainstream groups [63].

Sistani and colleagues [64-66] developed and pilot tested an Oral Health Literacy Adults Questionnaire
(OHL-AQ) which they state is valid and reliable. The OHL-AQ comprises four sections: reading comprehension, numeracy, listening, and decision-making. This tool was developed to address limitations of existing oral health literacy instruments, including their length, lack of generalizability across populations, and their focus on measuring either the ability of a person to read specific dental health vocabularies or the ability to read and comprehend oral health information and calculate numbers. Their aim was to develop a generic oral health literacy instrument for adults that included measures of listening and appropriate decision making. They argue that the OHL-AQ is a valid and reliable instrument for the functional assessment of adults' oral health literacy in community or population-based studies and because it is short and easy to use, could be used in clinical or research settings to improve oral health-related literacy skills and dentist-patient communication. The authors conclude that adding two new measures (listening and decisionmaking) improves the performance and quality of the existing instruments. They highlight that future research should include a larger population, in order to demonstrate the determinants of oral health literacy, particularly amongst those with limited general literacy skills.

\section{Conclusions}

The most widely used oral health literacy measurement tools are based on either the REALM or the TOFHLA. Findings from this scoping exercise confirm our findings from preliminary scans that the majority of tools are heavily biased towards word recognition, numeracy and reading skills, rather than what this means in terms of health behaviours and service utilisation. More recent developments have attempted to incorporate other aspects considered important, including decision making and possibly service navigation. The incorporation of these aspects should increase the validity of these tools as a measure of oral health literacy in its broader sense incorporating communicative/interactional and critical levels however formal validation work is required. In addition further work is required to develop tools adapted for specific populations tested to ensure acceptability and cultural competence. Lastly tools that are developed should be able to be used to determine risk and/or be sensitive enough to measure changes resulting from interventions.

\section{Competing interests}

The authors declare that they have no competing interests.

\section{Authors' contributions}

VDS, AK \& JK conceived and designed the scoping review and completed the first draft. VDS \& AK developed the search strategy, completed the database searches undertook the preliminary analysis of the findings with JF \& MG providing feedback on early drafts. VDS \& AK made final decisions about article verification with consensus from all authors. SL \& JF provided guidance and editorial support and all authors read and approved the final manuscript prior to submission. 


\section{Acknowledgements}

We acknowledging funding for this study from the National Health and Medical Research Council (Grant ID number: AP 1057362). The contents of this published material is the responsibility of La Trobe University as Administering Institution, partners or individual researchers and do not reflect the views of the NHMRC.

\section{Author details}

'La Trobe Rural Health School, La Trobe University, P.O. Box 199, Bendigo, Vic 3552, Australia. ${ }^{2}$ School of Medicine and Dentistry, James Cook University, 1 James Cook Drive, Townsville, QLD 4811, Australia.

Received: 22 August 2014 Accepted: 19 November 2014 Published: 4 December 2014

\section{References}

1. Healthy People: 2010 [http://www.healthypeople.gov]

2. World Health Organization: [http://www.who.int/topics/oral_health/en/].

3. National Institute of Dental and Craniofacial Research: The invisible barrier: literacy and its relationship with oral health. A report of a workgroup sponsored by NIDCR, USPHS, DHHS. J Public Health Dent 2005, 65:174-182.

4. Petersen PE, Bourgeois D, Ogawa H, Estupinan-Day S, Ndiaye C: The global burden of oral diseases and risks to oral health. Bull World Health Organ 2005, 83:661-669.

5. World Health Organization: What is the burden of oral disease? [http://www.who.int/oral_health/disease_burden/global/en/].

6. Australian Institute of Health and Welfare: Cost of dental care. [https://www.aihw.gov.au/dental/cost/].

7. Chriopolous S, Harford J: Oral Health Care and Dental Care in Australia: Key Facts and Figures 2012, Cat no DEN 224. Canberra: Australian Institute of Health and Welfare (AlHW); 2013.

8. Australian Health Ministers' Advisory Council (AHMAC): Oral Health of Australians: National Planning for Oral Health Improvement. Adelaide: (Department of Human Services SA) ed; 2001.

9. Richardson B, Richardson J: End the Decay: The Cost of Poor Dental Health and What Should be Done About it. Fitzroy, Melbourne: Brotherhood of St Laurence; 2011.

10. National Advisory Committee on Oral Health: Healthy Mouths, Healthy Lives: Australia's National Oral Health Plan 2004-2013. Canberra: National Advisory Committee on Oral Health; 2004.

11. Sabbahi DA, Lawrence HP, Limeback H, Rootman I: Development and evaluation of an oral health literacy instrument for adults. Community Dent Oral Epidemiol 2009, 37:451-462.

12. Jones M, Lee J, Rozier R: Oral health literacy among adult patients seeking dental care. J Am Dental Assoc 2007, 138:1199-1208.

13. Miller $E$, Lee J, DeWalt D, Vann W: Impact of Caregiver literacy on children's oral health outcomes. Pediatrics 2010, 126:107-114.

14. Nutbeam D: Health promotion glossary. Health Promot Int 1998, 13:349-364.

15. Baker D, Gazmararian J, Williams M, Scott T, Parker R, Green D, Ren J, Peel J: Functional health literacy and the risk of hospital admission among medicare managed care enrollees. Am J Public Health 2002, 92:1278-1283.

16. DeWalt DA, Berkman ND, Sheridan S, Lohr KN, Pignone MP: Literacy and health outcomes: a systematic review of the literature. J Gen Intern Med 2004, 19:1228-1239.

17. Nutbeam D, Kickbusch I: Advancing health literacy: a global challenge for the 21st century. Health Promot Int 2000, 15:183-184.

18. Rudd R, Horowitz A: Health and literacy: Supporting the oral health research agenda. J Public Health Dent 2005, 65:131-132.

19. Berkman ND, Sheridan SL, Donahue KE, Halpern DJ, Crotty K: Low health literacy and health outcomes: an updated systematic review. Ann Intern Med 2011, 155:97-107.

20. Kanj M, Mitic W: Health Literacy and Health Promotion. Geneva: World Health Organization; 2009

21. Kickbusch IS: Health literacy: addressing the health and education divide. Health Promot Int 2001, 16:289-297.

22. Nutbeam D: Health literacy as a public health goal: a challenge for contemporary health education and communication strategies into the 21st century. Health Promot Int 2000, 15:259-267.

23. Sorensen K, Van den Broucke S, Fullam J, Doyle G, Pelikan J, Slonska Z, Brand H, European CHLP: Health literacy and public health: a systematic review and integration of definitions and models. BMC Public Health 2012, $12: 80$

24. Osborne R, Batterham R, Elsworth G, Hawkins M, Buchbinder R: The grounded psychometric development and initial validation of the Health Literacy Questionnaire (HLQ). BMC Public Health 2013, 13:658.

25. Rothman RL, Montori VM, Cherrington A, Pignone MP: Perspective: the role of numeracy in health care. J Health Commun 2008, 13:583-595.

26. Schapira MM, Nattinger AB, McAuliffe TL: The influence of graphic format on breast cancer risk communication. J Health Commun 2006, 11:569-582.

27. Estrada CA, Martin-Hryniewicz M, Peek BT, Collins C, Byrd JC: Literacy and numeracy skills and anticoagulation control. Am J Med Sci 2004, 328:88-93.

28. Jordan JE, Buchbinder R, Briggs AM, Elsworth GR, Busija L, Batterham R, Osborne RH: The Health Literacy Management Scale (HeLMS): a measure of an individual's capacity to seek, understand and use health information within the healthcare setting. Patient Educ Couns 2013, 91:228-235.

29. Baker D: The meaning and the measure of health literacy. J Intern Med 2006, 21:878-883.

30. Nutbeam D: The evolving concept of health literacy. Soc Sci Med 2008, 67:2072-2078

31. Institute of Medicine: Health Literacy: A Prescription to end the Confusion. Washington DC: Institute of Medicine; 2004.

32. Davis TC, Long SW, Jackson RH, Mayeaux EJ, George RB, Murphy PW, Crouch MA: Rapid estimate of adult literacy in medicine: a shortened screening instrument. Fam Med 1993, 25:391-395.

33. Parker $R$, Baker D, Williams M, Nurss J: The test of functional health literacy in adults: a new instrument for measuring patients' literacy skills. J Gen Intern Med 1995, 10:537-541.

34. Parker $E$, Jamieson $L$ : Associations between Indigenous Australian oral health literacy and self-reported oral health outcomes. BMC Oral Health 2010, 10:3.

35. Jackson R, Eckert G: Health literacy in an adult dental research population: a pilot study. J Public Health Dent 2008, 68:196-200.

36. Baur C, Comings J, Evans C, Garcia R, Horowitz A, Ismail A, Kenyon D, Kirsch I, Kleinman D, Rudd R, Strucker J, Taylor G, White K: The invisible barrier: literacy and its relationship with oral health. J Public Health Dent 2005, 65:174-182

37. O'Malley L, Croucher K: Supported housing services for people with mental health problems: a scoping study. Housing Stud 2005, 20:831-845.

38. Arksey H, O'Malley L: Scoping studies: towards a methodological framework. Int J Soc Psychiatry Res Method 2005, 8:19-32.

39. Kenny A, Hyett N, Sawtell J, Dickson-Swift V, Farmer J, O'Meara P: Community participation in rural health: a scoping review. BMC Health Serv Res 2013, 13:64

40. Davis K, Drey N, Gould D: What are scoping studies? A review of the nursing literature. Int J Nurs Stud 2009, 46(10):1386-1400.

41. Giustini D, Kamel Boulos MN: Google Scholar is not enough to be used alone for systematic reviews. Online J Public Health Informatics 2013, 5:210

42. Parker EJ, Misan G, Chong A, Mills H, Roberts-Thomson K, Horowitz AM, Jamieson LM: An oral health literacy intervention for Indigenous adults in a rural setting in Australia. BMC Public Health 2012, 12:461.

43. Richman JA, Lee JY, Rozier RG, Gong DA, Pahel BT, Vann WF Jr: Evaluation of a word recognition instrument to test health literacy in dentistry: the REALD-99. J Public Health Dent 2007, 67:99-104.

44. Lee JY, Rozier RG, Lee SY, Bender D, Ruiz RE: Development of a word recognition instrument to test health literacy in dentistry: the REALD-30a brief communication. J Public Health Dent 2007, 67:94-98.

45. Vann WF Jr, Lee JY, Baker D, Divaras K: Oral health literacy among females caregivers: impact on oral health outcomes in early childhood. J Dental Res 2010, 89:1395-1400.

46. Hom JM, Lee JY, Divaris K, Baker AD, Vann WF: Oral health literacy and knowledge among patients who are pregnant for the first time. J Am Dent Assoc 2012, 143:972-980.

47. Atchison KA, Gironda MW, Messadi D, Der-Martirosian C: Screening for oral health literacy in an urban dental clinic. J Public Health Dent 2010, 70:269-275.

48. Holtzman JS, Atchison KA, Gironda MW, Radbod R, Gornbein J: The association between oral health literacy and failed appointments in adults attending a university-based general dental clinic. Community Dent Oral Epidemiol 2013, 42:263-270. 
49. Gironda M, Der-Martirosian C, Messadi D, Holtzman J, Atchison K: A brief 20-item dental/medical health literacy screen (REALMD-20). J Public Health Dent 2013, 73:50-55.

50. Gong DA, Lee JY, Rozier RG, Pahel BT, Richman JA, Vann WF Jr: Development and testing of the Test of Functional Health Literacy in Dentistry (TOFHLiD). J Public Health Dent 2007, 67:105-112

51. Macek MD, Haynes D, Wells W, Bauer-Leffler S, Cotten PA, Parker RM: Measuring conceptual health knowledge in the context of oral health literacy: preliminary results. J Public Health Dent 2010, 70:197-204.

52. Macek MD, Manski MC, Schneiderman MT, Meakin SJ, Haynes D, Wells W, Bauer-Leffler S, Cotton PA, Parker RM: Knowledge of oral health issues among low-income Baltimore adults: a pilot study. J Dent Hygiene 2011, 85:49-56.

53. Lee JY, Divaris K, Baker AD, Rozier RG, Vann WF Jr: The relationship of oral health literacy and self-efficacy with oral health status and dental neglect. Am J Public Health 2012, 102:923-929.

54. Lee JY, Baker AD, Rozier RG, Lee SY, Vann WF: Oral health literacy among a low-income WIC population. J Public Health Dent 2011, 71:152-160.

55. Stucky B, Lee J, Lee S, Rozier R: Development of the two-stage rapid estimate of adult literacy in dentistry. Community Dent Oral Epidemiol 2011, 39:474-480.

56. Lee J, Stucky B, Rozier G, Lee S, Zeldin L: Oral health literacy assessment development of an oral health literacy instrument for Spanish speakers. J Public Health Dent 2013, 73:1-8.

57. Wong HM, Bridges SM, Yiu CK, McGrath CP, Au TK, Parthasarathy DS: Development and validation of Hong Kong rapid estimate of adult literacy in dentistry. J Invest Clin Dentistry 2012, 3:118-127.

58. Wong H, Bridges S, Yiu C, McGrath C, Au T, Parthasarathy D: Validation of the Hong Kong Oral Health Literacy Assessment Task for Paediatric Dentistry (HKOHLAT-P). Int J Paediatr Dent 2013, 23:366-375.

59. Wells PL, Caplan DJ, Strauss RP, George M: An oral health survey of the Lumbee tribe in southern North Carolina. J Dent Hygiene 2010, 84:137-144.

60. Bridges SM, Parthasarthy DS, Wong HM, Yiu CK, Au TK, McGrath CP: The relationship between caregiver functional oral health literacy and child oral health status. Patient Educ Couns 2013, 94:411-416.

61. Bridges SM, Parthasarathy DS, Au TK, Wong HM, Yiu CK, McGrath CP. Development of functional oral health literacy assessment instruments: application of literacy and cognitive theories. J Public Health Dent 2014, 74:100-119.

62. Ueno M, Takeuchi S, Oshiro A, Kawaguchi Y: Relationship between oral health literacy and oral health behaviors and clinical status in Japanese adults. J Dental Sci 2013, 8:170-176

63. Jones K, Parker E, Mills H, Horowitz A, Brennan D, Jamieson L: Development and psychometric validation of a Health Literacy in Dentistry scale (HeLD). Community Dent Health 2013, in press.

64. Sistani MM, Yazdani R, Virtanen J, Pakdaman A, Murtomaa H: Determinants of oral health: does oral health literacy matter? ISRN Dentistry 2013, 4:1-9.

65. Sistani MM, Yazdani R, Virtanen J, Pakdaman A, Murtomaa H: Oral health literacy and information sources among adults in Tehran, Iran. Community Dent Health 2013, 30:178-182.

66. Sistani MM, Montazeri A, Yazdani R, Murtomaa H: New oral health literacy instrument for public health: development and pilot testing. J Invest Clin Dentistry 2013, 4:1-9.

doi:10.1186/1472-6831-14-148

Cite this article as: Dickson-Swift et al:: Measuring oral health literacy: a scoping review of existing tools. BMC Oral Health 2014 14:148.

\section{Submit your next manuscript to BioMed Central and take full advantage of:}

- Convenient online submission

- Thorough peer review

- No space constraints or color figure charges

- Immediate publication on acceptance

- Inclusion in PubMed, CAS, Scopus and Google Scholar

- Research which is freely available for redistribution

Submit your manuscript at www.biomedcentral.com/submit
C Biomed Central 